\title{
KONCEPCJA PRAWNA FINANSOWEGO STOSUNKU PRAWNORYNKOWEGO (ZARYS ZAŁOŻEŃ)
}

\section{WPROWADZENIE}

Prawo rynku finansowego jako dziedzina prawa jest stosunkowo młodym tworem dla badaczy prawa, a z uwagi na rzeczywistość gospodarczo-finansową i niedawne kryzysy finansowe niezwykle szybko i dynamicznie się rozwija ${ }^{1}$. Korzysta również z wielu nowych form działalności prawnej i zagospodarowuje coraz to nowe, dotychczas nieregulowane obszary stosunków społecznych ${ }^{2}$, których przedmiotem jest działalność (oferowanie produktów czy usług finansowych), a także bezpieczne funkcjonowanie instytucji zajmujacych się obrotem czy transferem środków finansowych oraz nadzór nad nimi ${ }^{3}$.

Odbiorcą rezultatów działalności szeroko pojętych instytucji finansowych są klienci rynku usług finansowych, a czasem również inne instytucje finansowe. To jednak dla klienta rynku usług finansowych, jako nieprofesjonalnej strony, tworzone sa ochronne zasady i wyznaczane standardy wzorcowego zachowania instytucji finansowych ${ }^{4}$. Dokonujący się rozwój nauki prawa rynku finansowego przejawia się w badaniach m.in.: sieci stabilności finansowej", miejsca klienta na rynku finansowym, zasad prawa szczególnie istotnych dla rynku finansowego ${ }^{6}$, działalności banków i charakteru norm ostrożnościo-

${ }^{1}$ E. Fojcik-Mastalska, Prawo rynku finansowego w systemie prawa, w: eadem, M. Olszak (red.), Prawo rynku finansowego. Doktryna. Instytucje. Praktyka, Warszawa 2016, s. 24 i n.; C. Kosikowski, Nowe prawo rynku finansowego Unii Europejskiej, w: E. Fojcik-Mastalska, M. Olszak (red.), op. cit., s. 32 i n.; A. Jurkowska-Zeidler, Prawo Unii Bankowej, w: E. Fojcik-Mastalska, M. Olszak (red.), op. cit., s. 84 i n.; C. Kosikowski, M. Olszak, Od prawa bankowego do prawa rynku finansowego, w: J. Głuchowski (red.), System prawa finansowego, t. 4, Warszawa 2010, s. 209 i n.

${ }^{2}$ M.in. rozdz. X ustawy z 23 marca 2017 r. o kredycie hipotecznym oraz o nadzorze nad pośrednikami kredytu hipotecznego i agentami (Dz. U. 2017, poz. 819).

${ }^{3}$ A. Jurkowska-Zeidler, Publicznoprawne formy oddziatywania państwa $i$ Unii Europejskiej na instytucje kredytowe i finansowe, w: J. Głuchowski (red.), op. cit., s. 251 i n.; M. Fedorowicz, Nadzór nad rynkiem finansowym Unii Europejskiej, Warszawa 2013, s. 150 i n.

${ }^{4}$ E. Rutkowska-Tomaszewska, Ochrona prawna klienta na rynku ustug bankowych, Warszawa 2013, passim.

${ }^{5}$ A. Jurkowska-Zeidler, Bezpieczeństwo rynku finansowego w świetle prawa Unii Europejskiej, Warszawa 2008, s. 166 i n.

${ }^{6}$ S. Kasiewicz, L. Kurkliński, W. Szpringer, Zasada proporcjonalności. Przełom $w$ ocenie regulacji, Warszawa 2014, passim. 
wych $^{7}$, zmieniających się zadań i funkcji współczesnej bankowości centralnej ${ }^{8}$, tworzenia podstaw teorii prawa rynku finansowego ${ }^{9}$, a także badaniach nowych zjawisk czy dotychczas nieregulowanych obszarów prawa rynku finansowego ${ }^{10}$ oraz sposobów tworzenia prawa rynku finansowego i jego stosowania ${ }^{11}$. Z kolei powiązania pomiędzy rynkiem finansowym a systemem finansów publicznych przejawiają się w rozwoju klauzuli bail-in, uzupełnianej zrównoważonym podejściem do działalności rekapitalizacyjnej państwa ${ }^{12}$.

Wpisując się w nurt teoretycznoprawnej analizy zależności na rynku finansowym (wzorem nauki prawa cywilnego czy administracyjnego), można również na gruncie prawa rynku finansowego postawić pytanie o potrzebę konstruowania, wyodrębnienia i charakterystyki finansowego stosunku prawnorynkowego jako stosunku powstajacego z normatywnego splotu stosunków cywilnoprawnego i administracyjnego w szczególnych warunkach i sytuacjach prawnych, związanych z zapewnieniem celu stabilności finansowej na rynku finansowym. Powstaje pytanie, jakie argumenty przemawiaja za wyodrębnieniem finansowego stosunku prawnorynkowego z teorii stosunków prawnych, znanych na gruncie nauki prawa cywilnego czy nauki prawa administracyjnego.

Stosunek administracyjnoprawny cechuje nierównorzędność podmiotów stron tego stosunku oraz brak dobrowolności nawiązania czy swobody ustalenia jego treści, a cywilnoprawny - zasadniczo równość i dobrowolność jego nawiązania; pierwszy jest oparty na normach prawa administracyjnego, a drugi - prawa prywatnego. Z kolei przedmiot stosunku administracyjnoprawnego należy do sfery działania administracji, regulowanej nakazami i zakazami, a cywilnoprawnego - do sfery prawa cywilnego, regulowanej za pomoca umów cywilnoprawnych, w których strony swobodnie mogą ustalać ich tresśćc ${ }^{13}$. Stosunek administracyjnoprawny charakteryzuje to, że po jednej stronie występuje

${ }^{7}$ M. Olszak, Bankowe normy ostrożnościowe, Białystok 2011, passim.

${ }^{8}$ M.in. O. Szczepańska, Stabilność finansowa jako cel banku centralnego. Studium teoretyczno-porównawcze, Warszawa 2008, passim; M. Fedorowicz, Nowe zadania i funkcje Europejskiego Banku Centralnego w zapewnianiu stabilności finansowej $w$ świetle regulacji Europejskiej Unii Bankowej, Warszawa 2016, passim; T. Knepka, Rola Europejskiego Banku Centralnego w zapewnieniu stabilności rynku finansowego Unii Europejskiej, Warszawa 2017, passim.

${ }^{9}$ M.in. M. Fedorowicz, Rola i zadania teorii prawa rynku finansowego UE, „Bezpieczny Bank" 2016, nr 1, s. 114-134.

${ }^{10}$ Zob. m.in. D. Cyman, Pojęcie pieniqdza i kierunki jego rozwoju, w: Z. Ofiarski (red.), XXV lat przeobrażeń $w$ prawie finansowym i prawie podatkowym - ocena dokonań $i$ wnioski na przysztość, Szczecin 2014, s. 681 i n.

${ }^{11}$ T. Nieborak, Tworzenie $i$ stosowanie prawa rynku finansowego a proces ekonomizacji prawa, Poznań 2016, passim.

${ }^{12}$ M. Fedorowicz, Prawne instrumenty urzeczywistniania stabilności finansowej na rynku finansowym UE w świetle rozporzadzenia 806/2014 i dyrektywy 2014/59/UE, „Krytyka Prawa” 9, 2017, nr 1, s. 15-31.

${ }^{13} \mathrm{Na}$ temat stosunku administracyjnoprawnego m.in. R. Hauser, Stosunek administracyjnoprawny, w: idem, Z. Niewiadomski, A. Wróbel (red.), System prawa administracyjnego, t. 1, wyd. 2, Warszawa 2015, s. 199 i n.; J. Lang, Stosunek administracyjnoprawny, w: M. Wierzbowski (red.), Prawo administracyjne, Warszawa 2017, s. 34 i n.; na temat stosunku cywilnoprawnego m.in. Z. Banaszczyk, Stosunek cywilnoprawny, w: M. Safjan (red.), System prawa prywatnego, t. 1: Prawo cywilne - część ogólna, Warszawa 2012, s. 935-1018. 
organ reprezentujący władztwo państwowe, a po drugiej - odbiorca nakazów i zakazów. W stosunku cywilnoprawnym nie występuje element władztwa i podporządkowania się kompetencjom jednego z podmiotów dysponującego władztwem państwowym bądź jego emanacją ${ }^{14}$. Na tym tle stosunek prawnorynkowy cechować będzie zazwyczaj nierówność podmiotów wobec prawa (zarówno formalna, jak i materialna), podległość podmiotowi dysponującemu władztwem państwowym czy dbającemu o urzeczywistnienie celu stabilności finansowej, a przedmiotem tego stosunku prawnorynkowego sa normy prawa rynku finansowego, składające się z interferujących norm prawa publicznego i prywatnego. Przy czym ani w stosunku administracyjnoprawnym, ani $\mathrm{w}$ stosunku cywilnoprawnym nie pojawia się na taką skalę, jak w przypadku stosunku prawnorynkoweg element normatywny w postaci zapewnienia celu stabilności finansowej przy nawiązaniu tego stosunku, opartego na pieniądzu.

Ze względu na interferencyjność norm prawa publicznego i prywatnego, funkcjonalnie sprzężonych we wszystkich regulacjach prawnorynkowych, oraz chęć ilustracji odrębności i specyfiki rynku finansowego warto pokusić się o stworzenie konstrukcji finansowego stosunku prawnorynkowego i uzasadnienie jej przydatności, a przynajmniej rozpoczać dyskusję na ten temat. Specyfika stosunku prawnorynkowego wynika stąd, że żaden inny obszar prawa tak mocno nie jest związany z ekonomia. Często do opisu zależności w prawie rynku finansowego stosuje się ekonomiczna analizę prawa do oceny i ,uchwycenia" relacji pomiędzy prawem a ekonomia, do ekonomicznej oceny skutków tworzonych i stosowanych norm prawnych. Ta „holistyka normatywna” wierniej wydaje się odzwierciedlać założenia prawodawcy i pozwala również od razu dostrzec wewnątrzsystemowe uwarunkowania i powiązania natury podmiotowej i funkcjonalnej oraz - lepiej i w ekonomiczno-gospodarczym kontekście - zrozumieć finansowe treści prawnorynkowe. Pozwala również tworzyć szczególne zasady wykładni tego obszaru prawa. Specyfika prawa rynku finansowego wymusza doktrynalną dyskusję nad precyzyjnym określeniem wszelkich cech wskazujących i uwypuklających swoistość tego prawa ${ }^{15}$.

Celem niniejszego artykułu jest pokazanie interferencji, „zazębiania się” wątków publicznych i prywatnych w ramach prawa rynku finansowego w zakresie tworzonej koncepcji finansowego stosunku prawnorynkowego. Dla realizacji tego celu podjęto próbę zarysowania doktrynalnej konstrukcji finansowego stosunku prawnorynkowego. Zaproponowano więc wstępna - z uwagi na ramy opracowania - analizę struktury prawnej tego stosunku, który jest odrębny od stosunku cywilnoprawnego i stosunku administracyjnoprawnego oraz wykazuje tak dalece idącą specyfikę prawną, że wymaga autonomicznego ujęcia, choćby z uwagi na potrzeby doktrynalne, orzecznicze czy dydaktyczne, a z pewnością wart jest podjęcia dyskusji doktrynalnej. Podstawą takiego podejścia są twierdzenia o tym, że prawo rynku finansowego jako dziedzina prawa powinna być traktowana całościowo, ,jako kompleks regulacji prawnych dotyczących organizacji i funkcjonowania rynku finansowego”, w której nie

${ }_{14}$ R. Hauser, op. cit., s. 199 i n.; Z. Banaszczyk, op. cit., s. 935 i n.

15 C. Kosikowski, M. Olszak, op. cit., s. 195 i n. 
ma potrzeby formalnego wyodrębniania prawa prywatnego rynku finansowego i prawa publicznego rynku finansowego z uwagi na specyfikę materii prawa rynku finansowego, która objawia się dopiero przy kompleksowej analizie regulacji i w której nie można przeprowadzić „wyraźnej linii demarkacyjnej”16.

Biorąc pod uwagę powyższe, w niniejszym artykule przyjmuje się, że finansowy stosunek prawnorynkowy określa wzajemne prawa i obowiązki dwu lub więcej podmiotów zawarte w normach prawa rynku finansowego urzeczywistniających cel stabilności finansowej.

\section{II. ŹRÓDŁA PRAWA FINANSOWEGO STOSUNKU PRAWNORYNKOWEGO}

Ze względu na powiązanie krajowego i unijnego systemu prawa w obszarze rynku finansowego, źródeł prawa dla finansowego stosunku prawnorynkowego można doszukiwać się zarówno w prawie UE, jak i w prawie polskim, co prowadzi do wniosku o dualistycznej naturze źródeł prawa stosunku prawnorynkowego, tzn. unijno-krajowej. Obszar prawa rynku finansowego należy zasadniczo do kompetencji unijnej dzielonej, nie może więc dziwić fakt, że źródła prawa rynku finansowego (w tym źródła finansowego stosunku prawnorynkowego) muszą mieć swoje normatywne zakotwiczenie w prawie UE i w prawie krajowym. Obszar prawa rynku finansowego coraz chętniej regulowany jest na szczeblu UE bezpośrednio skutecznymi i stosowalnymi rozporządzeniami, jak i rozporządzeniami wykonawczymi (tzw. wiążącymi standardami technicznymi - binding technical standards [BTS]), niepozostawiającymi dowolności czy opcyjności krajowym organom nadzorczym. Z uwagi na dualny charakter źródeł prawa rynku finansowego również źródła prawa stosunku prawnorynkowego mogą uzyskiwać i charakteryzować się taka podwójną natura.

Dziedzina prawa rynku finansowego wyodrębniła się stosunkowo niedawno, jej intensywny rozwój w Polsce należy łączyć z wejściem Polski do Unii Europejskiej i przyjęciem całego rynkowego aquis communataire, a także z implementacją i wykonywaniem nowych aktów prawa rynku finansowego ${ }^{17}$. $\mathrm{W}$ doktrynie prawa rynku finansowego podejmowanych jest wiele interesujacych wątków badawczych, które charakteryzuje właśnie mieszany, publiczno-prywatny charakter rozważań, z przewaga jednak elementu publicznego ${ }^{18}$.

Normy publicznoprawne, składające się zwłaszcza na organizację, nadzór i restrukturyzację instytucji finansowych, zyskuja ostatnio fundamentalne znaczenie. Przykładem instytucji (w sensie przedmiotowym) prawa rynku finansowego o takiej właśnie specyfice są m.in. tajemnica bankowa, restruktu-

16 E. Fojcik-Mastalska, op. cit., s. 24 i 26.

17 Ibidem, s. 20 i n.

18 Zob. m.in. zwłaszcza C. Kosikowski, M. Olszak, op. cit., s. 209 i n.; E. Fojcik-Mastalska, Bank centralny. Miejsce Narodowego Banku Polskiego w sieci bezpieczeństwa finansowego, w: R. Mastalski, E. Fojcik-Mastalska (red.), Prawo finansowe, Warszawa 2011, s. 455; C. Kosikowski, op. cit., s. 27 i n.; A. Jurkowska-Zeidler, Prawo..., s. 84 i n.; M. Olszak, op. cit., passim; M. Fedorowicz, Nadzór..., passim; T. Nieborak, op. cit., passim. 
ryzacja banków, nadzór nad rynkiem finansowym (m.in. w zakresie czynności bankowych czy norm ostrożnościowych). W zasadzie wszędzie tam, gdzie normy prawa rynku finansowego, nawet prywatnoprawne, wpływać mogą wzmacniająco lub destabilizująco na stabilność finansową (czyli element sytuacji na rynku finansowym należący do publicznoprawnej sfery prawa rynku finansowego), pojawia się możliwość, a można twierdzić, że wręcz konieczność ujmowania dualnej natury danej instytucji i jej specyfiki. Przykładem tej sytuacji mogą być np. wadliwie konstruowane wzorce umów, które w skali $n$-klientów, w skali makroostrożnościowej, mogą przyczyniać się do destabilizacji w sektorze bankowym czy generowania ryzyka systemowego ${ }^{19}$, a także poszerzanie obowiązków informacyjnych banków względem klientów i potencjalnych klientów na rynku kredytów hipotecznych (jest to bowiem materia, która może stać się źródłem ryzyka systemowego). Pokazuje to specyficzne zależności w prawie rynku finansowego, w ramach których normy prawa prywatnego stają się szczególnym punktem zainteresowania nadzorcy nad rynkiem finansowym, Rzecznika Finansowego czy innych jeszcze gremiów dbajacych o stabilność finansowa w skali kraju i w sferze prawa UE. Zawsze jednak ochrona klienta, ochrona instytucji finansowych przed trudnościami z płynnością i nieposzanowaniem norm ryzyka w działalności banków, likwidacja czy restrukturyzacja banku, a także jego upadłość będą wiązane ze stabilnością finansowa sektora rynku finansowego i stąd konieczny będzie również parasol ochronny norm prawa publicznego. Warto podkreślić, że finansowy stosunek prawnorynkowy m.in. w ujęciu nadzorczym może powstać nie tylko na podstawie decyzji krajowych organów nadzoru, ale również na podstawie europejskiej decyzji stosowania prawa (np. Europejski Organ Nadzoru Bankowego może w drodze takiej decyzji zakazać sprzedaży określonych produktów czy usług finansowych, właśnie z uwagi na potrzebę ochrony klienta rynku usług finansowych, zgodnie z art. 9 ust. 5 rozporządzenia nr 1093/2010) ${ }^{20}$.

Wydaje się zatem, że stabilność finansowa może i powinna stać się swoista wytyczna, wykładnikiem w procesie interpretacji norm prawa rynku finansowego i przesłanką rozważaną przy stosowaniu tychże norm, a przede wszystkim budulcem normatywnym finansowego stosunku prawnorynkowego. Przyjąć bowiem trzeba, że stabilność finansowa, w wielości jej znaczeń, podlega normatywizacji jako pojęcie prawne ${ }^{21}$. Stanowi ona przedmiot szerszego po-

19 Zob. szerzej i por. na ten temat zwłaszcza P. Frątczak, Umowy bankowe a stabilność finansowa, „Bezpieczny Bank” 2015, nr 4, s. 67-90.

${ }^{20}$ Rozporządzenie Parlamentu Europejskiego i Rady (UE) nr 1093/2010 z 24 listopada 2010 r. w sprawie ustanowienia Europejskiego Urzędu Nadzoru (Europejskiego Urzędu Nadzoru Bankowego), zmiany decyzji nr 716/2009/WE oraz uchylenia decyzji Komisji 2009/78/WE (Dz. Urz. L 331 z 15 grudnia 2010 r., s. 12 ze zm.); dalej jako: rozporządzenie o EBA (ang. European Banking Authority).

${ }_{21}$ M.in. A. Zalcewicz, referat: Stabilność krajowego systemu finansowego jako określenie stużace wyrażeniu normy prawnej (referat udostępniony za zgodą Autorki), Ogólnopolska Konferencja Naukowa „Rola bankowości centralnej w zapewnieniu stabilności finansowej rynku finansowego”, Wrocław, 17 maja 2013 r.; M. Fedorowicz, O normatywnym pojęciu stabilności finansowej na rynku finansowym Unii Europejskiej w nowej architekturze nadzorczej, „Studia Europejskie” 2017, nr 4, s. 73-94. 
jęcia bezpieczeństwa finansowego i mianownik normatywny dla Europejskiej Sieci Stabilności Finansowej ${ }^{22}$. Podwójna natura stosunku prawnorynkowego wynika również stąd, że relacja pomiędzy podmiotami na rynku finansowym oparta jest na pieniądzu, jego ruchu w systemie finansowym, a także jego wpływie nie tylko na stosunki prawne na rynku finansowym, ale również na system finansów publicznych i realną gospodarkę, co również wymaga regulacji za pomoca norm publicznoprawnych.

\section{PODMIOTY FINANSOWEGO STOSUNKU PRAWNORYNKOWEGO}

Sformułowanie „podmioty finansowego stosunku prawnorynkowego”, klasycznie rozumiane, powinno obejmować podmioty - uczestników rynku finansowego oraz podmioty nadzorujące ten rynek na poziomie krajowym i unijnym. Uczestnikami rynku finansowego są zarówno instytucje finansowe działające na rynku oraz ich klienci (konsumenci). Kryteriami stosowanymi w rekonstrukcji zakresu podmiotowego rynku finansowego sa: kto jest podmiotem uprawnionym do wykonywania usług finansowych na rynku finansowym i co z faktu tej podmiotowości wynika dla rynku czy systemu finansowego? ${ }^{23}$

Można również przeprowadzić rozróżnienie na istnienie stosunków prawnorynkowch pro foro externo i pro foro interno, stosunek taki może bowiem być nawiązany między nadzorca krajowym a instytucja finansowa, np. bankiem (pro foro interno), nadzorca unijnym a nadzorca krajowym (pro foro externo), czy nadzorca unijnym a instytucją finansowa (pro foro externo), zgodnie z regulacjami unijnego nadzoru nad rynkiem finansowym na podstawie rozporządzeń o ESA (m.in. w zakresie art. 17, 18 czy 19) ${ }^{24}$. Oczywiście stosunki prawnorynkowe moga przybierać albo zdecydowanie charakter cywilnoprawny: umowa rachunku bankowego, albo zdecydowanie charakter administracyjnoprawny: udzielenie zezwolenia na powstanie banku i prowadzenie przez niego działalności. Stosunki te moga jednak podlegać modyfikacji w drodze „wnikania" przez nadzór w normy prawa prywatnego (np. art. 138 ust. 7 Prawa ban-

${ }^{22}$ Szerzej A. Jurkowska-Zeidler, Bezpieczeństwo rynku..., passim.

${ }^{23}$ Zob. szerzej o zakresie podmiotowym C. Kosikowski, Nowe prawo rynku..., s. 29 i n.; M. Fedorowicz, Nadzór..., s. 225, 278 i 340.

${ }^{24}$ Rozporządzenie o EBA; rozporządzenie Parlamentu Europejskiego i Rady (UE) nr 1095/2010 z 24 listopada 2010 r. w sprawie ustanowienia Europejskiego Urzędu Nadzoru (Europejskiego Urzędu Nadzoru Giełd i Papierów Wartościowych), zmiany decyzji nr 716/2009/WE i uchylenia decyzji Komisji 2009/77/WE, Dz. Urz. UE L 331 z 15 grudnia 2010 r., s. 84 ze zm.; rozporządzenie Parlamentu Europejskiego i Rady (UE) nr 1094/2010 z 24 listopada 2010 r. w sprawie ustanowienia Europejskiego Urzędu Nadzoru (Europejskiego Urzędu Nadzoru Ubezpieczeń i Pracowniczych Programów Emerytalnych), zmiany decyzji nr 716/2009/WE i uchylenia decyzji Komisji 2009/79/WE, Dz. Urz. UE L 331 z 15 grudnia 2010 r., s. 48 ze zm. Rozporządzenia te, wspólnie z rozporządzeniem o EBA, stanowią tzw. rozporządzenia o ESA (ang. European Supervisory Authorities). 
kowego ${ }^{25}$ ), czy zwłaszcza przepisy restrukturyzacyjne w ustawie o Bankowym Funduszu Gwarancyjnym (tytułem przykładu art. 11 ust. 4 pkt 9-14, 19-21 ${ }^{26}$ ) dla urzeczywistnienia celu stabilności finansowej.

Potrzeba doktrynalnego wyodrębnienia stosunku prawnorynkowego może być uzasadniana: po pierwsze - koniecznością odnoszenia i oceny treści normatywnych prawa rynku finansowego (publiczno-prywatnych) do instytucji finansowych i do ich klientów w funkcjonalnym powiązaniu skutków, jakie mogą wywoływać w systemie finansowym w zakresie stabilności finansowej; po drugie - zasadnością odniesień do klauzuli bail-in na rynku finansowym, a tylko w ostateczności i na zasadzie wyjątku od zasady korzystania z pieniędzy publicznych; po trzecie - potrzebą lepszej ilustracji zjawiska przenikania się norm prawa publicznego i prawa prywatnego na rynku finansowym (zwłaszcza w efekcie zastosowania norm nadzorczych zarówno mikro-, jak i makroostrożnościowych), co może być również pomocne w procesie wykładni tych norm dla urzeczywistnienia celu stabilności finansowej.

Przy rekonstrukcji strony podmiotowej stosunku prawnorynkowego powstaje oczywiście kwestia ustosunkowania się do zagadnienia równości czy podległości stron tego. Również i w tym przypadku sprawa nie jest oczywista, charakterystyczna bowiem dla stosunku prywatnoprawnego równość stron (nawet w ramach czynności bankowych, które nawiązywane sa za pomoca środków i metod prawa cywilnego) doznaje pewnych ograniczeń. Wynika to z faktu, że - po pierwsze - banki jako oferenci sa silniejszymi gospodarczo podmiotami i narzucają klientom swoje warunki; po drugie - stosowania przez Komisję Nadzoru Finansowego (KNF) środków nadzorczych. Warto w tym miejscu przywołać istotną dla nadzoru bankowego zasadę ochrony pewności obrotu gospodarczego, wyrażoną w art. 138 ust. 7 u.p.b. Zgodnie z tym postanowieniem, umowy klientów z bankami wskutek zastosowanych środków nadzorczych przez KNF co do zasady pozostaja ważne, jak bowiem normuje się w tym postanowieniu: „środki podejmowane w ramach nadzoru nie moga naruszać umów zawartych przez bank”. Przepis ten stanowi zatem lex specialis do art. 58 k.c. i jest ukierunkowany na pewność obrotu bankowego z jednej

25 Ustawa z 29 sierpnia 1997 r. Prawo bankowe, t.jedn.: Dz. U. 2017, nr 1876 (dalej jako: u.p.b.).

${ }^{26}$ Ustawa z 10 czerwca 2016 r. o Bankowym Funduszu Gwarancyjnym, systemie gwarantowania depozytów i przymusowej restrukturyzacji, Dz. U. 2016, poz. 996 ze zm. (dalej jako: ustawa o BFG). BFG na podstawie art. 11 ust. 4 ustawy i w warunkach nim określonych wydaje decyzje w sprawach m.in.: zawieszenia wykonania wymagalnych zobowiązań podmiotu w restrukturyzacji; zawieszenia prawa do realizacji zabezpieczeń; zmiany warunków umów; zmiany warunków spłaty instrumentów dłużnych i innych zobowiązań; zawieszenia prawa jednostronnego rozwiązania umów zawartych z podmiotem w restrukturyzacji; zobowiąania do świadczenia usług $\mathrm{w}$ zakresie niezbędnym do prowadzenia działalności związanej z przeniesionymi: przedsiębiorstwem podmiotu w restrukturyzacji, prawami udziałowymi podmiotu w restrukturyzacji, wybranymi albo wszystkimi prawami majątkowymi lub wybranymi albo wszystkimi zobowiązaniami podmiotu w restrukturyzacji przez podmiot, na który sa przenoszone; zwrotnego przeniesienia przedsiębiorstwa, wybranych praw majątkowych, wybranych zobowiązań lub praw udziałowych, zwrotnego przeniesienia praw udziałowych w podmiocie w restrukturyzacji, przeniesienia przedsiębiorstwa, wybranych praw majątkowych lub zobowiązań; nakazania podmiotowi zbycia praw udziałowych w wyznaczonym terminie. 
strony, z drugiej zaś - na stabilność finansową w wymiarze $n$-klientów nadzorowanej instytucji kredytowej.

Stosunek prawnorynkowy może powstać na mocy prawa, ex lege, jak i poprzez wydanie decyzji administracyjnej. Warto przy tym zaznaczyć, że obok norm wiążących (rozporządzenia unijne, w tym również Binding Technical Standards, BTS, wiążące standardy techniczne, krajowe ustawy), także wytyczne i zalecenia unijnych oraz krajowych nadzorców dookreślają często sposób wykonania norm prawnorynkowych.

\section{PRZEDMIOT STOSUNKU PRAWNORYNKOWEGO}

Przy rekonstrukcji zakresu przedmiotowego stosunku prawnorynkowego istotne jest przyjęcie założenia o zmianie paradygmatu regulacyjnego na ryn$\mathrm{ku}$ finansowym, tzn. korzystaniu obecnie z regulacji prawnorynkowych o proweniencji nadzorczej27. Zakres prawa rynku finansowego, który może stanowić przedmiot stosunku prawnorynkowego, wyznaczany jest m.in. za pomoca katalogu usług finansowych (zawartych np. w załączniku do dyrektywy CRD IV ${ }^{28}$ ) czy też za pomoca zakresu kontroli i nadzoru sprawowanych na rynku finansowym $^{29}$.

Przedmiot prawa rynku finansowego w elemencie publicznoprawnym konstruowany być może z regulacji sektorowych rynku finansowego, zgodnie z wyraźnymi i w dużym stopniu jednolicie postawionymi przez każdy sektor warunkami czy wymogami. Tytułem przykładu w sektorze bankowym jest to podejmowanie i prowadzenie działalności przez instytucje kredytowe, w sektorze kapitałowym - podejmowanie i prowadzenie działalności przez firmy inwestycyjne i podmioty giełdowe, a na rynku ubezpieczeniowym - przez instytucje ubezpieczeniowe. Przedmiotem stosunku prawnorynkowego jest również stosowanie norm ostrożnościowych i innych norm dopuszczalnego ryzyka w działalności banków i innych instytucji finansowych. Warto w tym miejscu zwrócić uwagę na postanowienia art. 37 u.p.b. wskazujące przesłanki udzielenia zezwolenia na podjęcie działalności przez bank, w którym - jak można zauważyć - pojawiają się wątki związane ze stabilnością finansową klientów. Zgodnie z tym postanowieniem „Komisja Nadzoru Finansowego odmawia wydania zezwolenia na utworzenie banku lub na zmianę jego statutu, jeżeli nie zostały spełnione wymagania obowiązujące przy tworzeniu banków lub zamie-

${ }^{27}$ M. Fedorowicz, Nadzór..., s. 465.

${ }_{28}$ Zob. szerzej m.in. C. Kosikowski, Nowe prawo rynku..., s. 28 i n.; na temat zakresu przedmiotowego i podmiotowego prawa rynku finansowego zob. M. Fedorowicz, Nadzór..., s. 221-376. Zob. też dyrektywa Parlamentu Europejskiego i Rady nr 2013/36/UE z 26.6.2013 r. w sprawie warunków dopuszczenia instytucji kredytowych do działalności oraz nadzoru ostrożnościowego nad instytucjami kredytowymi i firmami inwestycyjnymi, zmieniająca dyrektywę 2002/87/WE i uchylająca dyrektywy 2006/48/WE oraz 2006/49/WE, Dz. Urz. UE L 176 z 27.6.2013, s. 338 (zwana dyrektywą CRD IV, ang. Capital Requirement Directive).

${ }^{29}$ M. Fedorowicz, Nadzór..., s. 221 i n. 
rzona działalność banku naruszałaby przepisy prawa, interesy klientów albo nie gwarantowałaby bezpieczeństwa gromadzonych w banku środków lub gdy przepisy prawa obowiązujące w miejscu siedziby lub zamieszkania założyciela lub jego powiązania z innymi podmiotami mogłyby uniemożliwić skuteczne sprawowanie nadzoru nad bankiem". Przesłanki ocenne uwzględnione w tym postanowieniu $\mathrm{w}$ istocie realizują treści zasady stabilności finansowej (bezpieczne gromadzenie środków, skuteczne sprawowanie nadzoru).

Dalej można także zauważyć, że zastosowanie przez KNF środka nadzorczego względem banku powinno uwzględniać możliwości naprawcze banku, przewiduje się bowiem rozróżnienie na środki nadzoru sanacyjnego i represyjnego, a efektem zastosowania środków nadzorczych ma być właśnie bezpieczeństwo działania banku i osiaganie celu stabilności finansowej, i to w ujęciu cyklicznym. W każdym praktycznie przypadku, w którym nawiązywany byłby stosunek prawnorynkowy, modyfikatorem strony przedmiotowej staje się cel stabilności finansowej. Jest on fundamentalny na rynku finansowym i osiągany powinien być zarówno w wymiarze mikro-, jak i makroostrożnościowym za pomoca norm prywatnoprawnych i publicznoprawnych. Można również formułować twierdzenia o występowaniu stabilności finansowej w wymiarze pojedynczego czy $n$-klientów instytucji finansowych. Stabilność finansowa jest nie tylko celem regulacji na rynku finansowym, lecz także wartością prawna, przesłanką prawną i zasadą w znaczeniu opisowym, jest zatem wielofunkcyjnym, słusznie elastycznym, pojęciem prawnym, którego znaczenie i funkcje powinny się objawiać zarówno na etapie powstawania stosunku prawnorynkowego, jego realizacji, jak i na etapie wykładni.

$\mathrm{Z}$ istotą stosunku prawnorynkowego wiąże się również zagadnienie istnienia interesu indywidualnego lub interesu publicznego. I również w tym przypadku można zauważyć, że w odniesieniu do materii prawa rynku finansowego, opartego na pieniądzu, wskazane dwa interesy są ze sobą mocno powiązane, funkcjonalnie zespolone, ponieważ interes indywidualny jest i powinien być rozpatrywany z uwzględnieniem zasady stabilności finansowej i minimalizacji generowania ryzyka systemowego. Jak bowiem pokazał kryzys na rynku kredytów hipotecznych subprime w Stanach Zjednoczonych, suma wadliwie konstruowanych umów i braków nadzorczych oraz niedoświadczenie i niedoinformowanie klientów mogły przyczynić się do wystapienia problemów finansowych. Skoro możliwe jest uznanie, że pewna suma wadliwie konstruowanych umów klientów z bankami i niedoświadczenie inwestycyjne klientów moga wpływać na generowanie ryzyka systemowego czy makroostrożnościowego, to oznacza to również, że interes indywidualny musi być rozstrzygany właśnie z uwzględnieniem celu stabilności finansowej, który w części odzwierciedla interes publiczny. W treści pojęcia interesu publicznego z kolei mieści się również uwzględnianie i poszanowanie relacji klientów z instytucjami finansowymi, co wyraża się chociażby w cytowanym i analizowanym już powyżej art. 138 ust. 7 u.p.b. czy restrukturyzacyjnych postanowieniach ustawy o BFG.

Przedmiot finansowego stosunku prawnorynkowego musi zatem zawierać $\mathrm{w}$ swej treści zarówno element publicznoprawny, jak i prywatnoprawny, 
konkretyzowany a casu ad casum przez pryzmat celu czy zasady stabilności finansowej, która jest swoistym spoiwem dla obszaru prywatnego i publicznego norm prawnorynkowych.

Dla przedmiotu prawa rynku finansowego i finansowego stosunku prawnorynkowego fundamentalne znaczenie ma również kwestia rekonstrukcji normy prawnorynkowej właściwej do zastosowania w danej konkretnej sytuacji, co dotyka również problematyki wykładni prawa rynku finansowego. Jej rekonstrukcja nierzadko musi odbywać się za pomocą aktów prawa z dwóch systemów prawnych: unijnego i krajowego oraz norm publicznych i prywatnych. Można uznać, że właśnie w połączeniu czy też interferencji norm prawa publicznego i prywatnego w obrębie prawa rynku finansowego przejawia się specyfika tego prawa i jego szczególna interpretacja, która uwzględniać powinna urzeczywistnienie celu stabilności finansowej na rynku i rzetelną ochronę klienta (zarówno za pomocą norm prawa prywatnego, jak i publicznego). Specyfika interpretacji norm prawa rynku finansowego wyraża się również w tym, że rekonstrukcja normy prawa rynku finansowego polega często na zestawieniu aktów prawnych krajowych z unijnymi, przy czym na szczeblu UE znajduje się całe bogactwo różnych form prawnych, począwszy od rozporządzeń i dyrektyw, poprzez regulacyjne i wykonawcze standardy techniczne, a na soft law nowej generacji unijnych nadzorców (doprecyzowujących czy określających sposób realizacji praw i obowiązków nadzorców krajowych czy instytucji finansowych) skończywszy. Bardzo często rekonstrukcja normy prawnorynkowej następuje zatem z uwzględnieniem i wykorzystaniem nie tylko rozporządzeń, dyrektyw, decyzji, wiążących standardów technicznych, lecz także z uwzględnieniem soft law unijnego (np. wytycznych i zaleceń EBA, zgodnie z art. 133 ust. 1a u.p.b.) i krajowego (rekomendacji KNF wydawanych na mocy art. 137 pkt 5 u.p.b.).

\section{PODSUMOWANIE}

Próba stworzenia teoretycznych podstaw prawa ryku finansowego, które pomagałyby w interpretacji prawa rynku finansowego i odkodowaniu przepisów regulujących zależności na rynku i w systemie finansowym, wydaje się interesującym, ważnym i potrzebnym celem badawczym, a jednym z jego elementów jest propozycja tworzenia konstrukcji finansowego stosunku prawnorynkowego. Argumentem przemawiającym za takim właśnie podejściem badawczym, który jednocześnie pokazuje skalę trudności analitycznej, jest przenikanie się materii prawa publicznego i prawa prywatnego w ramach prawa rynku finansowego. Powoduje to, że wszelkie teoretyczne koncepcje, jeśli mają być przydatne dla praktyki i teorii, powinny albo uwzględniać zarówno specyfikę materii publicznoprawnej, jak i prywatnoprawnej, albo wskazywać wyraźną klasyfikację i podział materii prawa rynku finansowego na część publiczną i część objętą normami prawa prywatnego ${ }^{30}$. Skoro w obecnym stanie

${ }^{30}$ E. Fojcik-Mastalska, op. cit., s. 19 i n. 
skomplikowania materii prawa rynku finansowego precyzyjny podział materii prawnorynkowej nie zawsze i nie we wszystkich sprawach wydaje się do końca możliwy, zadanie odkodowania wspólnych podstaw teoretycznych w zakresie budowy finansowego stosunku prawnorynkowego jest wyzwaniem dla przedstawicieli doktryny prawa rynku finansowego, a także organów dokonujących interpretacji tego prawa i stosujących je, gdyż to ostatecznie na nich spoczywa ciężar urzeczywistniania coraz bardziej normatywizującego się celu stabilności finansowej.

Kolejnym argumentem przemawiajacym za wyszczególnieniem finansowego stosunku prawnorynkowego i tworzeniem jego doktrynalnej koncepcji jest dualistyczny charakter źródeł prawa rynku finansowego (unijno-krajowy). I choć można by argumentować, że sytuacja taka nie jest przecież typowa jedynie dla rynku finansowego, dotyczy to bowiem innych obszarów regulacyjnych w systemie prawa, to jednak natura i charakter szczególnych powiązań, analogii i ujednoliceń natury instytucjonalnej i funkcjonalnej w tej sferze jest większy niż w przypadku innych dziedzin czy obszarów prawa, a łącznikiem jest tu normatywnie wyrażony cel stabilności finansowej, którego realizacji powinien służyć finansowy stosunek prawnorynkowy.

Finansowy stosunek prawnorynkowy powstawałby zatem z mocy prawa lub w wyniku wydania decyzji administracyjnej czy określonego nakazu bądź zakazu, w efekcie zastosowanych norm prawnorynkowych, tzn. zawsze wtedy, gdy po jednej stronie występować będzie np. instytucja finansowa, a po drugiej - jej nadzorca czy podmiot, którego celem działania jest zapewnienie stabilności finansowej (np. BFG), a także gdy po jednej stronie występować będzie klient, a po drugiej KNF (zwłaszcza w sytuacji wydania decyzji administracyjnej modyfikującej już istniejący stosunek cywilnoprawny).

Charakterystyczna dla stosunków cywilnych jest autonomia woli stron, która na rynku finansowym weryfikowana jest i kontrolowana przez silnie ukształtowane regulacje nadzorcze, co podyktowane jest wolą osiagnięcia celu stabilności finansowej, podlegającego coraz bardziej intensywnej normatywizacji. Finansowy stosunek prawnorynkowy, służący osiagnięciu tego celu, tym właśnie najbardziej odróżnia się od stosunku cywilnoprawnego i administracyjnoprawnego. Można też wskazać, że stosunkowi prawnorynkowemu towarzyszy wcześniej nawiązany stosunek cywilnoprawny, modyfikowany następnie powstajacym stosunkiem administracyjnoprawnym. Następująca dla osiagnięcia celu stabilności finansowej modyfikacja danej sytuacji prawnej wydaje się tak znaczna, że uzasadnia i wymaga analizy uwzględniajacej „nakładanie się” norm prawa cywilnego i administracyjnego, czyli skutków prawnych interferencji tych norm. Oczywiście na rynku finansowym występują również klasyczne stosunki cywilnoprawne czy administracyjnoprawne, jednakże wszędzie tam, gdzie pojawia się realizacja celu stabilności finansowej, czyli m.in. przeciwdziałanie ryzyku systemowemu w ujęciu cyklicznym (gdzie normy prawa administracyjnego „wkraczają" w nawiąane już stosunki cywilnoprawne lub też gdzie normy prawa cywilnego podlegaja „usztywnieniu” z uwagi na cel stabilności finansowej) dochodziłoby do powstania stosunku prawnorynkowego, który mógłby stanowić konstrukcję służąca analizie wszelkich konsekwencji prawnych zastosowanych 
norm w ramach danej sytuacji prawnej, pomagająca w realizacji czy ochronie celu stabilności finansowej. Istnieje możliwość porządkowania typów stosunków prawnorynkowych odpowiednio do strony podmiotowej. Możliwy wydaje się także dalszy podział tych stosunków na materialnoprawne (określone w normach prawa rynku finansowego) i proceduralne (konstruowane na podstawie przepisów postępowania administracyjnego lub cywilnego, ale uwzględniające cel stabilności finansowej).

Konstruowanie finansowego stosunku prawnorynkowego pozwala również odpowiedzieć na pytania, czym jest prawo rynku finansowego i gdzie w strukturze prawa ulokowany jest rynek finansowy, kto jest uczestnikiem działań na rynku finansowym i jaki jest zakres i materia tych działań, a następnie według jakich zasad i jakiego celu podejmowane są działania na rynku finansowym przez podmioty prawnorynkowe. Poza tym pozwala określić, jakie reguły i zasady są pomocne w objaśnianiu zależności stosunku prawnorynkowego oraz w jaki sposób i za pomocą jakich rekonstrukcyjnych modeli prawnych moga być rozstrzygane problemy na rynku finansowym, a także w jaki sposób i za pomoca jakich reguł interpretacyjnych organy orzekające moga (powinny) dokonywać wykładni prawa rynku finansowego. Wydaje się to szczególnie potrzebne z uwagi na interferencyjność norm tego obszaru stosunków społecznych i konieczność realizacji celu stabilności finansowej oraz silne powiązania prawa rynku finansowego $\mathrm{z}$ naukami ekonomicznymi.

Podstawowym problemem związanym z prawem rynku finansowego, łączacym w sobie elementy publicznoprawne i prywatnoprawne, oraz odzwierciedlającym te zależności finansowym stosunkiem prawnorynkowym jest znalezienie praktycznych rozwiązań zagadnień wynikających z przenikania się norm. Jeśli normy prawa publicznego na rynku finansowym wyznaczaja granice dla możliwych zachowań rejestracyjnych, licencyjnych, administracyjnych (czyli z szerokiego punktu widzenia nadzorczych), to pojęcia, terminy i zwroty służące osiagnięciu pewnych normatywnych czy regulacyjnych standardów na rynku finansowym wyrażone w normach prawa publicznego powinny podlegać doprecyzowaniu i uszczegółowieniu. Wszędzie tam, gdzie pojawia się nadzór, istnieć musi prawem wskazana granica działań władczych. Z drugiej strony cechą prawa cywilnego (w tym konsumenckiego) na rynku usług finansowych jest posługiwanie się elastycznymi pojęciami czy klauzulami, które jednak czasami ze względu na ochronę klienta podlegaja „usztywnieniu”. Wydaje się, że z punktu widzenia ochrony klienta na tym rynku zaobserwowana zależność stwarza sporo problemów interpretacyjnych czy konstrukcyjnych. Doprecyzowywanie klauzul czy zwrotów „należyta staranność”, „świadomy klient”, „racjonalne postępowanie” oznacza przyrost regulacji, inflację przepisów nadzorczych, a z drugiej strony coraz bardziej uszczegółowione przepisy nadzorcze (te zaś, choć wprowadzają transparentność i przejrzystość, to mają również charakter inflacyjny, spełniają rolę ograniczająca zasadę swobody umów w imię zapewnienia stabilności finansowej na rynku). Ta asymetria wydaje się nieunikniona, skoro kompleksowo analizowane aktywności uczestników na rynku usług finansowych opisywane są zarówno za pomocą norm publicznych, jak i prywatnych, a ogniskują się w teoretycznoprawnym 
ujęciu finansowego stosunku prawnorynkowego. A zatem jako remedium normatywne, orzecznicze czy interpretacyjne na obserwowane trudności analizy norm prawa rynku finansowego (w tym w szczególności pozycji klienta na ryn$\mathrm{ku}$ usług finansowych, borykającego się m.in z polisolokatami, kryzysem na rynku kredytów hipotecznych, kryzysem na rynku kredytów walutowych) można zaproponować rozważenie posługiwania się konstrukcją finansowego stosunku prawnorynkowego. Może ona być przydatna zwłaszcza w procesie szczególnej wykładni prawa rynku finansowego, która koncentruje się z jednej strony na zapewnieniu stabilności finansowej na rynku, a z drugiej - na ochronie klienta tego rynku i która godzi zazwyczaj wątki publiczne i prywatne występujące w danej sytuacji. Pamiętać trzeba jednak, że również różnego rodzaju aktywność klientów na rynku może wpływać na stabilność finansowa, a nieprawidłowo określony kształt normatywny przepisów czy ich niewłaściwe stosowanie moga przyczyniać się do wypaczenia owego celu i powstania ryzyka systemowego. Konstrukcja prawna stosunku prawnorynkowego może okazać się bardzo przydatna do modelowego (doktrynalnego czy orzeczniczego) ustalania treści niezbywalnej przepisów ochronnych na rynku finansowym. Normatywny standard tych przepisów wyznaczany byłby dodatkowo za pomoca modelowego ujęcia finansowego stosunku prawnorynkowego w postaci rozwiniętych wzorców ochronnych klienta dla każdego segmentu rynku, odrębnie z uwagi na ich specyfikę. Finansowy stosunek prawnorynkowy mógłby również doktrynalnie i orzeczniczo posłużyć do ustalenia szczególnej wykładni prawa rynku finansowego, polegającej m.in. na konieczności urzeczywistnienia dualnej czy też interferującej natury norm prawa rynku finansowego.

Ramy opracowania jako artykułu zapowiadającego i proponującego dyskusję na temat zasadności i potrzeby budowania koncepcji prawnej finansowego stosunku prawnorynkowego nie pozwalają oczywiście na wyczerpujace omówienie problematyki. Prezentowane rozważania mają stanowić jedynie głos i propozycję doktrynalnej dyskusji na ten temat.

dr hab. Magdalena Fedorowicz

Profesor Uniwersytetu im. Adama Mickiewicza w Poznaniu

magdalena.fedorowicz@amu.edu.pl

\section{THE LEGAL CONCEPT OF PRIVITY IN THE FINANCIAL MARKET LAW (GENERAL ASSUMPTIONS)}

$\mathrm{Sum}$ m a r y

The aim of the paper is to explain the interference of public and private norms in the financial market on the example of legal relationships created under financial market law. This paper shows the reasons and opinions regarding the doctrinal need to create such a concept and recognises the urgent need of its institutionalisation in the doctrine. Privity in financial market law that arises between parties is significantly different from the civil and administrative law relations and due to doctrinal, judicial and didactic reasons requires an autonomous approach. The analysis conducted in this paper presents the views and ideas of how to better evolve and explain the legal relationships existing in the financial market law, also theoretically, and is expected to ignite a serious doctrinal discussion on this subject. 
